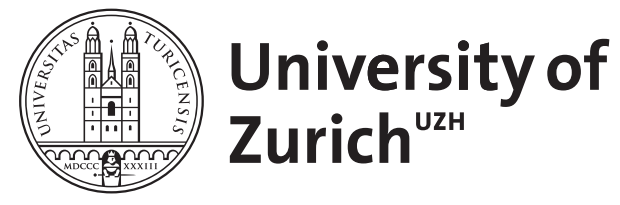

From the savannah to the magistrate's court: The roots of criminal justice in evolved human psychology

Eisner, Manuel ; Murray, Aja Louise ; Ribeaud, Denis ; Averdijk, Margit ; van Gelder, Jean-Louis

DOI: https://doi.org/10.1515/9783110472974-004

Posted at the Zurich Open Repository and Archive, University of Zurich

ZORA URL: https://doi.org/10.5167/uzh-166442

Book Section

Accepted Version

Originally published at:

Eisner, Manuel; Murray, Aja Louise; Ribeaud, Denis; Averdijk, Margit; van Gelder, Jean-Louis (2017). From the savannah to the magistrate's court: The roots of criminal justice in evolved human psychology. In: Jann, Ben; Przepiorka, Wojtek. Social Dilemmas, Institutions, and the Evolution of Cooperation. Berlin: de Gruyter, 61-83.

DOI: https://doi.org/10.1515/9783110472974-004 


\title{
From the Savannah to the Magistrate's Court
}

\section{The Roots of Criminal Justice in Evolved Human Psychology}

\author{
Manuel Eisner \\ Institute of Criminology, University of Cambridge \\ Aja Louise Murray \\ Institute of Criminology, University of Cambridge \\ Denis Ribeaud \\ Department of Sociology, Swiss Federal Institute of Technology \\ Margit Averdijk \\ Department of Sociology, Swiss Federal Institute of Technology \\ Jean-Louis van Gelder
}

Netherlands Institute for the Study of Crime and Law Enforcement (NSCR) 


\begin{abstract}
Recent research claims that criminal justice institutions have universal features that are rooted in psychological mechanisms shaped by human evolution. In this paper we review three core questions related to this perspective: We first examine the notion that our evolved psychology has led to cross-culturally shared intuitions about what constitutes a crime. We then assess the extent to which arguments based on behavioral game theory and evolutionary psychology can account for the emergence of centralized punishment in complex societies. Finally, we examine procedural fairness as a pivotal normative element of criminal justice across the world.

We show substantial cross-cultural variability in what is considered a crime and propose a theoretical perspective that recognizes change in the normative bases of cooperative behavior. Second, we also argue that seeing criminal justice primarily as a system that imposes costs on free-riders may be incomplete. In particular, we highlight fair procedure and legitimacy as core characteristics that distinguish institutionally anchored justice from mere punishment.
\end{abstract}


Wherever states have emerged over the past 4,000 years, institutions developed that we easily recognize as 'criminal justice' --- arrangements to deal with wrongs and deliver punishment. Examples include ancient China, Babylon, India, Egypt classical Greece, and the Inca, Maya and Aztec Empires (Avalos 1994; Calhoun 1927; Doniger 1991; Harper 1904; Johnson 1995; Krotz 2001; Lorton 1977). This universal formation of criminal justice institutions in large-scale societies raises questions at the core of sociological thinking. Why are some behaviors punishable and not others? How does punishment contribute to social order? And why do societies have elaborate procedures to do justice?

These questions are not new. Social theorists such as Hobbes (1968 [1660]), Locke (1988 [1690]), Beccaria (1764), Mill (1991 [1859]) and Nozick (1974) have examined extensively what behaviors should be punished, and how criminal justice contributes to social order. One answer is based on social contract theory. It begins by assuming that all individuals share fundamental rights to pursue their self-interests such as life, liberty and property. In their search for a way to protect these rights rational actors agree on a social contract in which centralized punishment is the main mechanism to enforce compliance with the contract. In this model, social contract theory makes highly stylized assumptions about human nature. In particular, it assumes that individuals are solitary beings who act rationally in pursuit of their self-interest.

Recent scholarship has questioned whether these assumptions are realistic. In particular, behavioral game theorists and evolutionary psychologists have argued that basic features of criminal justice are deeply rooted in complex emotional and cognitive mechanisms that were shaped during human evolution. The claims are bold: Buckholtz and Marois (2012: 655), for example, maintain that "third-party punishment of norm violations $[\ldots]$ is the cornerstone of modern systems of criminal justice", while Petersen et al. (2012: 682) propose that "intuitions about modern mass-level criminal justice systems emerge from evolved mechanisms designed to operate in ancestral small-scale societies".

Supportive evidence comes from different disciplines. This includes behavioral game theory experiments on the conditions for cooperative behavior in groups (e.g. Fehr and Gächter 2002; Gintis et al. 2008); evolutionary psychology research on the 
roots of moral sentiments and punitive intuitions in the recurrent problems of cooperation and free-riding in hunter-gatherer societies (e.g. Petersen et al. 2010; Price, Cosmides and Tooby 2002; Walsh 2000); and neuroscientific studies on the brain circuitry involved in processes such as anger, revenge, norm compliance and equity (Buckholtz and Marois 2012; McCullough, Kurzban and Tabak 2013; Spitzer et al. 2007). However, there have been few efforts to link findings from laboratory and experimental research to the body of criminological knowledge about criminal justice 'in the wild'.

It is currently unclear to what extent an evolutionary approach can explain realworld features of criminal justice. To shed some light on this issue, we therefore review three issues that we believe are critical for the viability of an evolutionary framework: We first examine the claim that our evolved psychology has led to cross-culturally shared intuitions about what constitutes a crime. We then assess the extent to which findings emerging from behavioural game theory can account for the emergence of centralized punishment in complex societies. Finally, we analyse how game theory and evolutionary psychology may explain procedural fairness as a pivotal normative element of criminal justice across the world.

\section{What is in the Criminal Law?}

What makes some behaviours crimes? There is disagreement within the social sciences about the right answer to this question. The standard social science model (Tooby and Cosmides 1992) assumes that perceptions of what is crime are highly variable between societies. Durkheim (2010 [1895]) for example, argued that anything that violates shared values can become seen as a crime. Similarly, sociological conflict theories expect substantial variation although here the changing interests of the ruling classes determine which behaviors become labeled as crimes (Quinney 1970).

Other theories predict that intuitions about crime are highly similar across human societies. Evolutionary theories, in particular, hold that criminal law is a social institution that builds on evolved psychological mechanisms designed to solve the problem of free-riding among genetically unrelated individuals (Petersen et al. 2010; 
Robinson, Kurzban and Jones 2007). Accordingly, crime is seen as the behavior of exploitative predators who have a preference for non-cooperative, short-sighted, coercive, and egoistic strategies (Duntley and Shackelford 2008; Glenn, Kurzban and Raine 2011; Petersen et al. 2010: 686; Robinson, Kurzban and Jones 2007). Hence criminal law, the argument goes, consists of punitive norms that protect a group against cheating and harm-doing. In this vein, Robinson et al. (2007) maintain "that people broadly share intuitions that serious wrongdoing should be punished and also share intuitions about the relative blameworthiness of different transgressions" across cultures. Therefore we should expect those behaviors to be universally punishable that undermine cooperation by violating reciprocity and fairness rules (Fehr and Schmidt 1999). Criminologists Gottfredson and Hirschi identified this core as acts of "force and fraud" (Gottfredson and Hirschi 1990).

\subsection{Cross-cultural Similarities}

How strong is the evidence that universal intuitions about wrongdoing shape a crosscultural consensus about what is crime? Supportive findings come from several strands of research, although there is a continuing lack of empirical work outside Western societies. First, several anthropological and criminological studies have examined comparatively which behaviours are perceived as deserving of punishment across societies (Hoebel 1967; Newman 1976; Newman 2010; Reichel 2002). Work by Newman (1976) conducted in the early 1970s has remained an important standard in the field. Comparing India, Indonesia, Iran, Italy, the United States and Yugoslavia he found important similarities in what is considered a crime across these cultures. In particular, physical integrity and property are protected by legal norms in all studied societies, while there is more cross-cultural variation in the criminalization of moral transgressions relating to sexual behavior and religion.

Second, criminologists have studied agreement in crime seriousness estimates both between individuals within a society and between societies (Stylianou 2003). Within a society these studies suggest a very high between-individual agreement on the relative ranking of different crimes (Robinson and Kurzban 2006). When one considers the ranking of average scores between societies a high correlation is also found for those 
crimes where the victim suffers a visible and unambiguous damage or injury (Newman and Wiolfgang 1976). For such behaviors the seriousness ranking mainly mirrors intuitions about the size of the inflicted harm. Thus, murder, rape and robbery tend to rank high, while simple theft and assaults without serious injuries rank low (Stylianou 2003).

A third group of studies have examined the factors that influence people's intuitions about the proper punishment for a wrongdoing. They often use vignettes and manipulate salient elements of a criminal act (Carlsmith 2006; Crockett, Özdemir and Fehr 2014; Stylianou 2003). Most respective work has been done in Western societies, where findings suggest that subjects punish primarily on the basis of a retribution principle. This means that punitive intuitions are for the most part driven by three factors: the magnitude of harm; the extent to which the perpetrator is perceived to have acted intentionally; and extenuating circumstances such as provocation, or self-defense that might mitigate the immorality of the act (Carlsmith 2006; Cushman 2015). This retributive pattern is broadly in line with a core expectation from evolutionary theory, namely that punishment serves to inflict costs on actors who egoistically use force against others or exploit the cooperative behavior of others (Crockett, Özdemir and Fehr 2014).

\subsection{Historical and Cross-cultural Variability}

However, what is punished by criminal law also varies substantially across cultures and over time. To illustrate the issues we examined a convenience sample of seven major state-organized historical cultures across the world. Table 1 summarizes the results. In line with the cross-cultural universalism hypothesis they suggest that behaviors such as homicide, theft, and fraud were universally punished across this sample. However, the table also comprises a considerable proportion of behaviors that are specific to one or several cultures (e.g. the emphasis on crimes against the social hierarchy in Imperial China or the criminal prohibition of alcohol consumption in Sharia Law). Furthermore, it shows that many historical cultures heavily criminalized several large groups of behaviors that have almost entirely been dropped from modern Western criminal law (Schwartz 1963). This includes sexual behaviors (adultery, 
homosexuality), offences against religion (e.g. blasphemy), and harm-doing through magical means (e.g. witchcraft).

[Table 1 about here]

Few systematic studies on perceived crime seriousness have included non-Western societies. An exception is the survey by Evans and Scott (1984), which comprised student samples in Kuwait and the United States in the late 1970s. When comparing the average seriousness rankings for 37 norm-breaking behaviors in both societies the authors found a small and non-significant association (rho $=.264$, n.s.). In particular, while there was broad agreement on the relative seriousness of property, violent, and white-collar offenses, large inconsistencies were found for moral offenses. For example, adultery by a married woman was the most severe crime in Kuwait, but the fifth least severe behavior in the United States, and the strength of religious beliefs predicted differences between individuals in each society.

Criminal law also goes through often slow, but sometimes radical change over time. An example is the criminal code that Louis Michel le Peletier presented to the French National Constituent Assembly in 1791, which proposed to abolish all "phony offenses created by superstition, feudalism, the tax system, and [royal] despotism" (Martucci 2002). It outlined, inspired by Montesquieu and Beccaria, a more rational law limited to the 'true crimes' against citizen's rights in public space, physical integrity, the exchange of goods, and private property. Behaviors that had carried the death penalty barely a century earlier -- blasphemy, witchcraft, heresy, sacrilege, and same sex activities -- were discarded and became a matter of private preferences.

Peletier's revolutionary ideas were part of a broader historical trend in perceptions of what deserves punishment. 'Moral crimes' (consensual sexual behaviors, obscenity, promiscuity, adultery) and crimes against supernatural beings (blasphemy, heresy, witchcraft) were gradually removed from the books across western society. At the same time the protection of physical integrity was extended, possibly as part of what Durkheim (1957) called the rise of moral individualism. It can be seen, amongst others, in the elimination of provisions that allowed the top-down use of force against subjects 
of authority including marital rape, the corporal punishment of children, or the chastisement of wives, pupils, or apprentices (Pinker 2011).

Also, modern criminal law embodies principles that have roots in the abstract universalism of modern political thought rather than in evolved intuitions. Especially, the abstract idea that "all are equal before the law" is a powerful normative principle of European liberal thinking. It probably squarely contradicts evolved intuitions. Thus, Petersen et al. (2010) have proposed that human evolution should have shaped punitive intuitions that take into account the value of the victim and the perpetrator when assessing the wrongfulness of a crime. This is what one finds in hunter-gatherer societies, where the killing of group members unfit for survival (the elderly, the injured, or the disabled) was often perceived as justifiable (Hoebel 1967). Similarly, criminal law thinking in many state-organized historical societies graded punishments by the social status of the perpetrator and the victim (Roth 2014). The tariff tables of the early medieval Visigothic code of law, for example, show that assaulting a slave was punished less than attacking a free man, while a slave striking a free person was the most serious crime (Scott 1910).

\subsection{Accounting for Stability and Change}

How strong is the evidence for cross-culturally universal intuitions about what constitutes crime? It seems that some criminalizing beliefs can be found quite universally. This includes the belief that punitive sanctions are deserved for unprovoked attacks on physical integrity (assault, murder, rape), the appropriation of others' property (theft, robbery), the abuse of contractual obligations (fraud), and activities against the polity (rebellion, sedition, treason). The punishment of fraud, theft and force, it appears, constitute the universal core of criminal law.

In contrast, much more cross-cultural variation can be seen for a second group of behaviors (Serajzadeh 2008; Wasserman 1983; West and Green 1997). It encompasses transgressions against sexual propriety (adultery, fornication, incest, homosexual practices), reputational capital (insult, false accusation), religious beliefs (blasphemy, sorcery, witchcraft), and the use of mind-altering substances (alcohol, drugs). 
Limited work has examined the sources of such variation. One argument follows Durkheim (1893). It holds that change in the set of punished behaviors mirrors change in the inner qualities required for cooperation and social cohesion. Two such qualities have been variously identified as essential in societies with only limited state protection, namely 'honour' (Cohen and Nisbett 1994) and a shared belief in moralizing gods (Norenzayan 2013). Cohen and Nisbett (1994) argue that weak protection of property rights in herding societies universally leads to the rise on masculine honour, feuding and revenge cultures as a recognized counter-mechanism against possible exploitation by others (also see, e.g. Boehm 2011; Gluckman 1955). Norenzayan (2013), in turn, has argued that a shared belief in moralizing gods played a pivotal role for the development of co-operation among strangers in the first large-scale societies, which could explain the widespread criminalization of behaviors harmful to supernatural beings. The gradual 'decriminalization' of offensive behaviors against morals, religious beliefs, and public reputation may hence reflect long-term change in the basis for cooperation. In modern societies it can be achieved through contractual obligations in ways that are largely indifferent to the personal moral quality of the participants.

\section{The Evolutionary Basis of Punishment}

The most downright expression of criminal law is centralized punishment, the infliction of unpleasant outcomes upon an individual on behalf of the polity (see table 1). Punishment systems developed in all larger societies with differentiated power structures, and there are important cross-cultural commonalities in the types of costs that were imposed on perpetrators. They include financial compensation (fines); reputational damage (e.g. pillory, branding, degradation ceremonies); pain, mutilation, and death (e.g. whipping, gouging out eyes, castration, amputation of extremities, stoning, boiling, drowning, hanging, burning); ostracism (e.g. banishment, deportation and exile); and deprivation of liberty (e.g. servitude, slavery and imprisonment) (Allen 2003; Berdan 2008; Miethe and Lu 2005; Roth 2014; Windrow 2006).

One approach to understanding the rise of state-led punishment applies behavioral game theory models to evolutionary psychology. It assumes that punishment uses 
psychological mechanisms such as anger, revenge or a sense of fairness, and that these mechanisms were sculpted by evolution in the service of promoting co-operation whilst protecting against exploitation (e.g. de Waal \& Brosnan, 2006; Haushofer \& Fehr, 2008; Petersen et al., 2010). For example, Petersen et al. (2010: 682) argue that modern intuitions about criminal justice have been structured by "our evolved counterexploitation psychology".

\subsection{Strong Reciprocity and Third-Party Punishment}

Evidence for such an evolved counterexploitation psychology can be found in work on 'strong reciprocity' in experimental behavioral economics (Gintis 2000). Strong reciprocity (or 'altruistic punishment') relates to the willingness by third parties to sacrifice resources in both rewarding fair behavior and punishing unfair behavior, even if this is costly and provides neither present nor future economic rewards for the reciprocator.

Strong reciprocity was first identified in experimental studies in the late 1990s. These studies examined how the involvement of a third party influences the extent to which cooperation can be maintained in iterated economic games (Fehr and Fischbacher 2004; Fehr and Gächter 2002; Gintis et al. 2008). The experiments usually comprised ultimatum games. In these games one player ('the proposer') determines the split of a financial reward while a second player ('the responder') chooses to accept or reject the proposer's offer. If the responder refuses the offer, both players lose the entirety of the reward. In the third party-punishment form of the game a third player ('the observer') can use their resources to impose costs on the proposer.

Evidence from hundreds of variants of the game has led to two conclusions. Both fly in the face of economic rationality. First, responders tend to reject offers that are 'unfair' even when a rational cost-benefit analysis suggests that they would be better off accepting (Diekmann 2004). Second, when third party players observe 'unfairness' (e.g. the proposer in the ultimatum game making a very low offer to the receiver) they are willing to expend some of their resources to reduce the welfare of the proposer, even if they do not personally benefit from doing so. The findings have been interpreted as signs of a deep seated sense for justice: They suggest that humans are willing to incur 
costs for the sake of inflicting punishment when they perceive allocations as unfair, and they even do this if they are not directly affected by the injustice.

Seminal studies by Henrich et al. (2006) show that the desire to punish actors who behave unfairly is a cross-cultural universal (Buckholtz and Marois 2012). Heinrichs et al. (2006) conducted ultimatum and third-party punishment games in 15 societies from five continents and representing a variety of economic and social systems. Across all societies the third-party players showed a willingness to punish highly unequal offers, although the punishment was costly for them. However, the authors also found that the average inclination to punish varied substantially between societies.

Other studies have examined the conditions under which cooperation can be maintained in iterated public goods games. These are games where a number of players make choices about the amount they wish to contribute to a shared 'public' pot, and where the payoff is then evenly distributed to all players. Results from this research suggest that the maintenance of co-operation depends on the facility for third party, respectively altruistic punishment. That is, participants in public goods games stop cooperating if they cannot control the behavior of those who attempt to cheat the system (Diekmann and Przepiorka 2015; Fehr, Fischbacher and Gächter 2002; Herrmann, Thöni and Gächter 2008). Conversely, cooperation can be maintained once players are given the option of inflicting costs on cheaters. Non-cooperative strategies will still be attempted. Yet the costs that self-interested players anticipate for non-cooperative strategies means that cooperation can prevail.

Finally, behavioral experiments also shed light on the proximal psychological mechanisms that trigger punishment. In particular, Fehr and Gaechter (2002) found that participants who failed to contribute their share to a public good elicited anger in other players. Moreover, the intensity of anger was proportional to the difference between the cheater's contribution and the average contributions by the others. In the framework developed by evolutionary psychologist Robert Trivers (1971), these emotions can be thought of as representing 'moralistic aggression', feelings of anger and retaliation in response to those who don't reciprocate prior cooperative behavior. Trivers proposed that "a sense of fairness has evolved in the human species as the standard against which to measure the behavior of other people, so as to guard against cheating in reciprocal 
relationships" (Trivers 1985). More recently, McCullough et al. (2013) mapped out the details of such a 'revenge system' as a set of evolved psychological mechanisms that function to impose costs on would-be aggressors.

\subsection{The Emergence of Sanctioning Institutions}

If criminal justice has roots in evolved cognitive-emotional processes that facilitate third-party punishment, how could such mechanisms become institutionalized in systems with police officers, judges, defense lawyers, prosecutors, and prison officers (Buckholtz and Marois 2012: 657)? Robinson el al. (2007) proposed one possible answer. They speculate that specialization may be attributable to different skills within a society. Thus, a tendency to delegate punishment to specialists can emerge from the human desire to see wrongdoers punished while not wishing to individually pay the costs of inflicting punishment, coupled with the preference for finding closure and peace following a conflict (Robinson, Kurzban and Jones 2007).

Similarly, Cushman (2015) sees criminal justice as an example of institutional exaptation. Exaptation is the process whereby a trait originally evolved for one purpose is later exploited for another. He argues that humans' taste for retribution and justice are largely innate. They protect against exploitation. However, personally engaging in punishment is risky because it can elicit cycles of retaliation and counter-retaliation. Thus, criminal justice establishes an authority (a 'social contract') run by specialists. It delivers third party punishment based on explicit ex ante rules, while drawing on psychological motivations that have evolved during our ancestral past.

One problem with this idea is what game theorists refer to as the second order public good dilemma (Diekmann and Przepiorka 2015; Ostrom 2000). While criminal justice addresses the first order problem of exploitation by others, it creates a new problem the second order public good dilemma -- of why actors should participate in the maintenance of this institutional mechanism.

Recent behavioral game theoretical experiments have begun to shed light on this question (Diekmann and Przepiorka 2015; Gürerk, Irlenbusch and Rockenbach 2006; Zhang et al. 2014). For example, initial evidence supports the idea that competition between groups with varying levels of punitive mechanism could have played a role in 
the rise of sanctioning institutions. Gürerk et al. (2006) conducted a study where participants could choose between playing an iterated public goods game in a sanctionfree and non-punitive versus a sanctioning environment. In the sanctioning environment players are informed, after each round, about the contributions of the other players in their group, and they can then use their tokens to positively or negatively sanction others. Initially most participants preferred a sanction-free institution. However, ultimately the entire population of participants migrated to the sanctioning institution, where strong reciprocators maintained cooperation.

This suggests that societies with sanctioning mechanisms may do better than those without. Diekmann and Prezepiorka (2015) provide insight into a possible mechanism. They examined the role of individual differences in the ability --- operationalized as differences in costs --- to punish free-riders. In a second-order public goods game (i.e. a game designed to understand the conditions under which actors contribute to the maintenance of a sanctioning mechanism) they evaluated the impact of assigning participants different costs of punishing others. They found that when administering punishment was less costly for some participants, the other participants tended to hand over the responsibility to those 'punishment specialists'. Furthermore, groups with an unequal distribution of punishment costs --- amounting to a greater incentive to 'centralize' punishment --- performed better in terms of reducing cheating and maintaining cooperation than those with an egalitarian distribution of punishment costs.

These findings suggest that centralized punishment can emerge entirely through endogenous processes. The authors hence argue that the growth of inequality and the emergence of coalitions of power holders in the wake of the Neolithic revolution may have created conditions ripe for the emergence of centralized punishment, which in turn would have helped consolidate monopolies of violence and support rent extraction (Diekmann and Przepiorka 2015). Criminal justice, then, may be so ubiquitous across large-scale civilized societies because punishing institutions were necessary to facilitate successful interaction among strangers in complex societies with a high division of labour.

There is a problem with this argument, though. Until the very recent past criminal justice institutions were weak and punishment was rare and unpredictable - professional 
policing, for example, is an invention of the $19^{\text {th }}$ century (Emsley 1991). The emergence of cooperation and trust in the first complex societies hence likely required additional mechanisms that punished cheaters and free-riders. In this vein, psychologist Ara Norenzayan (2013) has highlighted the importance of imagined punishment by moralizing high gods. In his view, it wasn't not just the punitive power of the state that initially paved the path to co-operation. Rather, the "Big Gods" of the religions that emerged simultaneously with the rise of state-organized societies played a major role. Their all-knowing, all-powerful, and morally-concerned qualities made them excellent third-party punishers that watch over human behavior and thus help stabilize cooperation in large groups. They ultimately dominated the cultural landscape --- the cultural evolution argument by Norenzayan (2013) goes ---- because belief in Big Gods gave the believers a competitive edge over other groups.

\subsection{Keeping Punitive Emotions at Bay}

The anthropological record suggests that ancient societies found dealing with obvious free-riders, psychopaths, or bullies relatively easy. If public shaming failed, death penalties would be imposed and carried out by designated individuals (Boehm 2012). The truly dangerous problem, it seems, were over-zealous second and third party punishers who would ruminate revenge against group members that had inflicted prior harm. In fact, vengeance is a major motivating force behind homicide cross-culturally with blood-feuds or similar types of self-redress found in $90 \%$ of the 186 societies in the Standard Cross-Cultural Sample (McCullough, Kurzban and Tabak 2013).

Also, punishers do not always have the welcome effect of protecting a public good and facilitating compliance. In sociology, Donald Black (1983) argued over 30 years ago that much crime is a form of punitive self-help: It often originates in a situation that the perpetrator perceives as unfair or harmful; and the eventual 'crime' is frequently motivated by the wish to take action against the perceived injustice. Empirical research has since provided ample support for this idea. Some young people believe that it is "right to fight to protect your friends" or that "standing up to protect your rights" justifies getting into a fight. Across the world they are more rather than less likely to break the law (Ribeaud and Eisner 2015; Trajtenberg and Eisner 2014). They morally 
neutralize their harmful behavior by restructuring it as private justice (Bandura et al. 1996). Furthermore, they tend to be cynical about the rule of law and often claim a private obligation to punish wrongdoers (Nivette et al. 2014).

We illustrate the threat that peer-to-peer punishers pose with an example about vengeful ruminations. The data come from the z-proso study, an ongoing longitudinal study of 1675 young people who entered primary school in 2004 in the city of Zurich (Eisner and Ribeaud 2005). At age 17 we asked respondents about their violent fantasies during the past 30 days (Murray et al. 2016). Several items refer to ideations of second and third party punishment, such as "paying back with violence for something done to myself", "paying back with violence for something done to somebody I know", or "killing somebody who has insulted my family or my friends".

The findings show a deep gap between what people do and what they imagine they might do: Switzerland has some of the lowest rates of violence in the world. However, fantasies about violent punishment are widespread. Thus, one out of five (19\%) young people had recently fantasized about killing a person they know; $26 \%$ had thought about violently retaliating for harm done to somebody they know; and $37 \%$ had thought about violent payback for harm done to themselves. If young people carried out the punishments they ruminate about, Zurich would quickly be wiped out in a civil war.

We next explored a hypothesis about the triggers of vengeful ruminations. Thus, evolutionary arguments lead us to expect that human brains generate virtual action plans for violent retaliation especially when the organism experiences fitness threats (Kenrick and Sheets 1993; McCullough, Kurzban and Tabak 2013). We explored this idea by examining the association between violent ideations and serious violent victimization during the past year.

[Table 2 about here]

In line with predictions based on evolutionary theory males were more likely to have violent ruminations than females, irrespective of their victimization. Also, victims of violence had more ruminations of second and third party retaliation than non victims. However, this effect was almost entirely limited to male respondents. For example, 
male victims were more than twice as likely as non-victims to ruminate about killing a person they know (39\% vs. 15\%), while no difference could be found for female victims. This suggests that very substantial proportions of male victims of violence have ruminations about retaliatory violence. These ruminations are not about fair and proportionate justice. They are about the desire to kill..

Thankfully young people do not usually act on the violent ideations that are triggered by threats to their reputation or physical integrity. One reason is a functioning state. It controls would-be punishers by claiming a monopoly over the use of violence. Thus, criminal justice institutions, with their emphasis on due process and adherence to universal rules (i.e. the rule of law), are probably not merely a functional extension of third-party punishment. Rather, they also serve to control ancient punitive impulses in increasingly complex societies. In the ancestral egalitarian groups conflict going out of hand through self-reinforcing cycles of violent punitive sanctions was a constant threat. Modern criminal justice is designed to do the opposite, namely to immunize justice from the emotional processes and intuitions that may be part of our evolutionary nature (Cushman 2015).

\section{Procedural Fairness and Compliance with Criminal Law}

Criminal justice differs from private third-party punishment not just because it is centralized. It differs mainly because of the formal procedures designed to identify suspects, establish guilt, and inflict punishment. In modern societies especially, every stage of criminal justice from police arrest to sentencing and parole are in the limelight of public interest about procedural fairness: Is the police racist? Do rapists get away without punishment too often? Do prisons fail to deter from re-offending because they are too soft? Is caning inhumane? Etc.

Emerging evidence suggests that our emotional and moral preoccupation with matters of fair procedure is not a recent phenomenon. Rather, fairness is critical for the extent to which third-party punishment promotes cooperation, and the interest in how the game is played may be rooted in our evolved psychology (Boehm 2012; Bøggild and Petersen 2016). 


\subsection{Evolutionary Roots of Procedural Fairness}

Bøggild and Petersen (2016: 256) recently proposed that the ancestral environment of humans favoured a keen interest in procedural fairness -- mechanisms that regulate how decisions come about. They argue that humans have a universal desire for fairness, and that this desire reflects the ancestral problem of allocating leadership rights to those individuals within a group that coordinate group efforts effectively and maintain peace and cooperation among its members (Bøggild and Petersen 2016: 256).

Fair procedure was likely especially important when decisions had to be made about punishment against somebody accused of a crime. Crimes are rarely transparent and group members will often disagree about who did what. If no consensus is found, the punishment risks producing conflict that can undermine future co-operative behavior. Moreover, the moral quality of acts that entail inflicting harm on others is not obvious. Inflicting harm could be an exploitative cheating strategy, and hence a morally wrong 'crime'; but it could also be a morally rightful punishment for prior wrongful acts.

This problem is not always sufficiently recognized. Duntley and Shackelford (2008), for example, argue that inflicting costs on rivals to gain control over their resources is what defines crime. The problem is: inflicting costs on others is also the essence of punishment. In fact, throughout human history inflicting harm on others could always be both things: wrongful acts of crime or rightful acts in response to previous wrongs. Different parties would have had different self-serving views, and failure to address such conflicts could lead to antagonistic alliances that easily rip a group apart (Boehm 2012).

The need to solve these problems may have created a pressure for the evolution of the psychological mechanisms behind our interest in fair procedure: Giving the relevant parties an opportunity to be heard, estimating the impartiality of those who deliver judgment, and applying consistent procedures over time (Boehm 2012; Bøggild and Petersen 2016; Bottoms and Tankebe 2012; Tyler 1990). This does not necessarily require a rational process based on witnesses and evidence. Procedures that involve supernatural interference such as trial by water or fire may have served exactly this 
purpose. They helped to overcome the impasse that no human being could be trusted to be free from conflicts of interest.

Few behavioral game theory experiments have examined the effects of procedural fairness on cooperative behavior. One exception is a study by de Cremer and Van Knippenberg (2003). In this study subjects played an iterated public goods game where they decided how much of an endowment they wanted to contribute to a public pot. In each round a group leader decided on which group members received a share of the public pot, effectively punishing those who failed to contribute their share. In two versions of the experiment the authors manipulated two aspects of procedural justice: In the first version they manipulated the extent to which the group leader had accurate information on the subjects' contributions to the public good. In the second version the authors manipulated whether participants could voice their opinions before the leader decided on how to divide the pot. Findings showed that among those who were punished (i.e. receiving less than their the equal share of the total sum) the willingness to cooperate in future rounds was significantly lower if the leader did not have accurate information and if they were not given a voice in the decision process.

Third-party punishment has a dark side. Experiments show, for example, that some players use their punitive ability to take revenge on co-operative players for prior punishment (Leibbrandt and López-Pérez 2011). Recently, Hilbe and Traulsen (2012) presented findings from an evolutionary game-theory model that examined the emergence of responsible punishment, in other words punishment strategies that are not antisocial (i.e. harming cooperators), spiteful (i.e. harming everyone) or vengeful (i.e. as a response to being punished). They showed that non-anonymity of the punishment decision may be a critical factor. More specifically, their models suggest that responsible punishment dominates in conditions of non-anonymity because such strategies confer reputational gains to the actors, making fair punishment a selfinterested act rather than an altruistic service to the community.

\subsection{The Significance of Legitimacy and Procedural Fairness}

The legitimacy theory framework by Tyler (1990) and Bottoms and Tankebe (2012) assumes that centralized punishment is more likely to maintain cooperation if it is 
legitimate and fair (Eisner and Nivette 2012; Nivette and Eisner 2012). In particular, a lack of legitimacy - the right to rule and the recognition by the ruled of that right (Bottoms and Tankebe 2012) - is expected to threaten cooperation and result in more crime and violence.

The historical and anthropological record demonstrates how much humans valued procedural fairness: Among the Yurok, a native American people in Northwestern California, complex precautions were taken to ensure that the group handling legal cases was neutral and seen as legitimate (Hoebel 1942). Similarly, the payment of blood money in contemporary South Sudan follows a complex legal procedure. It includes foundational agreements, mechanisms for information gathering and truth-telling, careful selection of a mediating third party, examination of truces, compensation agreements, closing rituals, and implementation measures (Wilson 2014). Also, false accusation is a chronic problem whose negative consequences were much feared in early societies. Thus, the first three of the 282 laws of the famous Law Code by the Babylonian king Hammurabi (around 1750 BC) penalize reputation-damaging activities (Harper 1904). The third law, for example, states that "if any one bring an accusation of any crime before the elders, and does not prove what he has charged, he shall, if it be a capital offense charged, be put to death". The message is clear: Justice can be subverted by rumors and false accusations, and due process based on evidence should characterize good justice.

In the contemporary world countries differ in the extent to which their citizens believe that the law is applied fairly, and that criminal justice is in the hands of those who should have the authority to punish. Also, observational data suggest that a lack of legitimacy significantly erodes people's willingness to comply with the law (Nivette and Eisner 2012; Tyler 2006). The mediating mechanisms are not understood well, but evidence suggests that an important factor is procedural justice, i.e. the perception that the police and the courts are transparent, accountable, and fair (Jackson et al. 2012). Unfortunately, there is a lack of consolidated experimental evidence on the effects of procedural fairness on cooperation in third-party punishment games. However, some experimental work confirms that legitimate authority plays an important role in sustaining cooperation (Hilbe and Traulsen 2012). Overall, this suggests that 
bureaucratic criminal justice institutions are thus not merely a functional extension of third-party punishment. What sets it apart is that citizens see punishment as a rightful act delivered by legitimate authorities in a transparent and accountable manner, based on the rule of law (Fehr and Gächter 2002).

\section{A Real-world Example: The Peace of God Movement of the $10^{\text {th }}$ and $11^{\text {th }}$ Century}

Evolutionary psychology and behavioral game theory experiments lead to general models of how criminal justice systems may have emerged. They are designed to provide a framework for understanding real-life historical dynamics. To illustrate this potential we briefly examine one historical example, namely the Peace and Truce of God movement of the $10^{\text {th }}$ and $11^{\text {th }}$ century (Cowdrey 1970; Head 1999; Head and Landes 1992). It was a major initiative by the Church aimed at limiting the violence of feuding in a society with hardly any central state authority. Its importance can hardly be overestimated. It constitutes one of the earliest attempts to establish and enforce peace as a public good, and is hence a critical moment in the process by which punishment became gradually more concentrated in the hands of state monopolists, while other protection providers were eliminated (Spierenburg 1984; Tilly 1985; Weber 1978 [1922]).

The Peace of God movement was launched by bishops in Aquitaine in south-west France around the year 1000, spreading across France in the following decades. It was explicitly directed against the warrior elite whose relentless local feuds meant that they took ecclesiastical property by force, plundered agricultural resources from peasants, and attacked unarmed clerics (Head 1999: 655).

Against this background the archbishop of Bordeaux called a council in 989 at the abbey of Charroux to address the 'criminal actions' of the local nobility. The meeting of the religious authorities resulted in a proclamation that used the most powerful punishment the church had: It threatened the magnates with excommunication for acts involving the plundering of churches, the robbing of the poor, or the attack of unarmed clerics. 
Over the following decades the bishops developed an increasingly sophisticated multi-tiered approach towards establishing peace: They convoked councils attended by the leading moral authorities; they orchestrated an elaborate ritual drama by having relics of saints ceremonially transported to the sites of the councils to provide divine authority; and they attracted large crowds in open fields to generate a moral community. But most importantly: they had members of the warrior elites publicly take oaths of peace. These oaths, called 'treuga dei' (Truce of God), usually entailed a commitment to renounce from feuding and private warfare during pays of peace, usually from Thursday through Sunday and during religiously important periods. They became an important centre of legislative action, as the bishops enrolled the most influential public powers in the administration, adjudication, and enforcement of the oaths (Cowdrey 1970).

The Peace of God movement largely lacked the means of physical coercion, and it is unclear whether it effectively achieved a pacification of the warrior elites. However, over the following two centuries the idea of proclaiming a peace that outlaws violence --- sometimes just for some days of the week or against some specified groups --- was co-opted by the secular authorities. It eventually became, in the guise of the "King's Peace" (the 'Landfrieden' in Germany), a core element of the notion of sovereign power and a justification for considering acts such as murder, rape or assault not as a matter of private compensation but as a breach of the social contract and a reason for public punishment (O'Brien 1999). At least in theory, these truce days were the first moments in European history where public authority claimed a monopoly on the legitimate use of violence though the emerging criminal justice system (Spierenburg 2008).

The Peace of God movement is a fascinating example for the complex strategies that contemporaries used to overcome a Hobbesian situation where self-interested behavior by warrior elites leads to cycles of revenge and continuous attacks against the weak. Possible in line with the arguments by Diekmann and Przepiorka (2015) about the importance of power coalitions, the movement towards criminalizing elite theft and violence was begun by the most influential moral authorities of the day. Also, as suggested by Norenzayan (2013), it seems that the movement compensated for the lack of wordly power by the extensive reference to the punitive might of the moralizing 
Christian god against those who break his peace. Finally, the Peace of God movement built the kind of procedural fairness into the peacemaking between feuding parties that de Cremer and Knippenberger (2003) and Hilbe and Traulsen (2012) would lead us to expect: The literate clergy increased transparency by producing written records about what had happened, the punishments for the past behavior, and the oaths and peace agreements between magnates. They held public councils with visible rituals of reconciliation to give the involved parties a voice and promote responsible behavior. And they recorded contributions to the public good such as donations to monasteries as displays of cooperative intentions.

Furthermore, the Peace of God movement points to additional processes that would be useful to examine theoretically. For example, from the onset the movement used powerful ideological elements of the 'pax Romana', the period of prosperity and peace that began with the reign of Augustus. May be this idea of a truce that overcomes anarchy and solves the commons dilemma may be interpreted as a 'meme', a cultural idea that shaped the further development of legal thinking across the whole of occidental Europe (Richerson and Boyd 2008).

\section{Conclusions}

Recent work coming out of behavioral game theory experiments and evolutionary psychology has crucially added to our understanding of the psychological underpinnings of criminal justice. In this paper we have outlined three core questions that arise when findings from macro-level comparative research are interpreted in the light of experimental research in behavioral economics and sociology. First, we believe that the historical and cross-cultural variability in what is considered punishable wrongdoing requires a flexible framework. Acts of fraud, theft and force, it appears, constitute the universal core of behaviors that manifestly undermine human cooperation. They are hence most likely to be proscribed as 'crimes', and sanctions generally are proportional to perceived harm. At the same time, for many other behaviors cultures differ significantly in the extent to which they are considered wrongful and deserving of punishment by the polity. 
Second, we believe that seeing criminal justice primarily as a system that imposes costs on free-riders risks ignoring its important role in controlling peer punishment and protection by private protection entrepreneurs. Especially, we have highlighted the problem that unchecked punishment may undermine rather than promote cooperation. Third, we have highlighted the significance of fair procedure and legitimacy as core characteristics that distinguish institutionally anchored justice from mere punishment. We therefore believe that behavioral experiments that model fair procedure could help to better understand the long-term transition towards a centralized, bureaucratic, and legitimate criminal justice system. Finally, believe that the well-documented development of criminal justice institutions over the past 1000 years in Europe offers opportunities to put evolutionary arguments to interesting tests 'in the wild', adding rich historical data. 


\section{References}

Allen, Danielle S. 2003. "Punishment in Ancient Athens." in Athenian Law in its Democratic Context (Center for Hellenic Studies On-line Discussion Series). , edited by Adriaan Lanni.

Avalos, Francisco. 1994. "An overview of the legal system of the Aztec Empire." Law Library Journal 86:259-76.

Bandura, Albert, Claudio Barbaranelli, Gian Vittorio Caprara, and Concetta Pastorelli. 1996. "Mechanisms of moral disengagement in the exercise of moral agency." Journal of personality and social psychology 71(2):364.

Beccaria, Cesare. 1764. Dei delitti e delle penne.

Berdan, Frances. 2008. "Living on the edge in an ancient imperial world: Aztec crime and deviance." Global Crime 9(1-2):20-34.

Black, Donald. 1983. "Crime as Social Control." American Sociological Review 48(1):34-45.

Boehm, Christopher. 2011. "Retaliatory Violence in Human Prehistory." British journal of criminology 51(3):518-34.

-. 2012. Moral Origins: The Evolution of Virtue, Altruism, and Shame. New York: Basic Books.

Bøggild, Troels, and Michael Bang Petersen. 2016. "The evolved functions of procedural fairness: An adaptation for politics." Pp. 247-76 in The Evolution of Morality, edited by Todd K. Shackelford and Ranald Hansen. Cham: Springer.

Bottoms, Anthony, and Justice Tankebe. 2012. "Beyond procedural justice: A dialogic approach to legitimacy in criminal justice." The journal of criminal law and criminology 102(1):119-70.

Buckholtz, Joshua W., and Rene Marois. 2012. "The roots of modern justice: cognitive and neural foundations of social norms and their enforcement." Nature Neuroscience 15(5):655-61.

Calhoun, George Miller. 1927. The Growth of Criminal Law in Ancient Greece. Berkeley: University of California Press.

Carlsmith, Kevin M. 2006. "The roles of retribution and utility in determining punishment." Journal of Experimental Social Psychology 42(4):437-51.

Cohen, Dov, and Richard E. Nisbett. 1994. "Self-protection and the culture of honor: Explaining Southern violence." Personality and Social Psychology Bulletin 20(5):551-67.

Cowdrey, Herbert Edward John. 1970. "The Peace and the Truce of God in the eleventh century." Past \& Present (46):42-67.

Crockett, Molly J., Yagiz Özdemir, and Ernst Fehr. 2014. "The value of vengeance and the demand for deterrence." Journal of Experimental Psychology. General 143(6):2279-86.

Cushman, Fiery. 2015. "Punishment in humans: From intuitions to institutions." Philosophy Compass 10(2):117-33.

De Cremer, David, and Daan Van Knippenberg. 2003. "Cooperation with leaders in social dilemmas: On the effects of procedural fairness and outcome favorability in structural cooperation." Organizational Behavior and Human Decision Processes 91(1):1-11.

Diekmann, Andreas. 2004. "The power of reciprocity; Fairness, reciprocity, and stakes in variants of the dictator game." Journal of Conflict Resolution 48(4):487-505.

Diekmann, Andreas, and Wojtek Przepiorka. 2015. "Punitive preferences, monetary incentives and tacit coordination in the punishment of defectors promote cooperation in humans." Scientific reports 5.

Doniger, Wendy. 1991. The Laws of Manu. London: Penguin UK.

Duntley, Joshua D., and Todd K. Shackelford. 2008. "Darwinian foundations of crime and law." Aggression and Violent Behavior 13(5):373-82.

Durkheim, Emile. 1893. De la division du travail social: étude sur l'organisation des sociétés supérieures: Presses Universitaires de France.

—. 1957. Professional Ethics and Civic Morals. London: Routledge \& Kegan Paul.

Durkheim, Émile. 2010 [1895]. Les règles de la méthode sociologique: Editions Flammarion. 
Eisner, Manuel, and Amy Nivette. 2012. "How to reduce the global Homicide rate to 2 per 100,000 by 2060." Pp. 219-28 in The Future of Criminology., edited by Rolf Loeber and Brandon C. Walsh. New York: Oxford University Press.

Eisner, Manuel, and Denis Ribeaud. 2005. "A Randomised Field Experiment to Prevent Violence: The Zurich Intervention and Prevention Project at Schools, ZIPPS." European Journal of Crime, Criminal Law and Criminal Justice 13(1):27-43.

Emsley, Clive. 1991. The English Police: A Political and Social History. New York: St Martin's Press.

Evans, Sandra S., and Joseph E. Scott. 1984. "The seriousness of crime cross-culturally:. The impact of religiosity." Criminology 22(1):39-59.

Fehr, Ernst, and Urs Fischbacher. 2004. "Third-party punishment and social norms." Evolution and Human Behavior 25(2):63-87.

Fehr, Ernst, Urs Fischbacher, and Simon Gächter. 2002. "Strong reciprocity, human cooperation, and the enforcement of social norms." Human Nature 13(1):1-25.

Fehr, Ernst, and Simon Gächter. 2002. "Altruistic punishment in humans." Nature 415(6868):137-40.

Fehr, Ernst, and Klaus M Schmidt. 1999. "A theory of fairness, competition, and cooperation." The Quarterly Journal of Economics 114(3):817-68.

Gintis, Herbert. 2000. "Strong reciprocity and human sociality." Journal of theoretical biology 206(2):169-79.

Gintis, Herbert, Joseph Henrich, Samuel Bowles, Robert Boyd, and Ernst Fehr. 2008. "Strong reciprocity and the roots of human morality." Social justice research 21(2):241-53.

Glenn, Andrea L, Robert Kurzban, and Adrian Raine. 2011. "Evolutionary theory and psychopathy." Aggression and Violent Behavior 16(5):371-80.

Gluckman, Max. 1955. "The Peace in the Feud." Past \& Present (8):1-14.

Gottfredson, Michael T., and Travis Hirschi. 1990. A General Theory of Crime. Stanford: Stanford University Press.

Gürerk, Özgür, Bernd Irlenbusch, and Bettina Rockenbach. 2006. "The competitive advantage of sanctioning institutions." Science 312(5770):108-11.

Hanawalt, Barbara A. 1979. Crime and Conflict in English Communities, 1300-1348. Cambridge: Cambridge University Press.

Harper, Robert Francis. 1904. The Code of Hammurabi, King of Babylon: About 2250 BC: Autographed Text, Transliteration, Translation, Glossary Index of Subjects, Lists of Proper Names, Signs, Numuerals. Chicago: Chicago University Press.

Head, Thomas. 1999. "The development of the Peace of God in Aquitaine (970-1005)." Speculum 74(03):656-86.

Head, Thomas F, and Richard Allen Landes (Eds.). 1992. The Peace of God: Social Violence and Religious Response in France around the Year 1000. Ithaca: Cornell University Press.

Henrich, Joseph, Richard McElreath, Abigail Barr, Jean Ensminger, Clark Barrett, Alexander Bolyanatz, Juan Camilo Cardenas, Michael Gurven, Edwins Gwako, and Natalie Henrich. 2006. "Costly punishment across human societies." Science 312(5781):176770.

Herrmann, Benedikt, Christian Thöni, and Simon Gächter. 2008. "Antisocial punishment across societies." Science 319(5868):1362-67.

Hilbe, Christian, and Arne Traulsen. 2012. "Emergence of responsible sanctions without second order free riders, antisocial punishment or spite." Scientific reports 2.

Hobbes, Thomas. 1968 [1660]. The Leviathan. Harmondsworth: Penguin.

Hoebel, E. Adamson. 1942. "Fundamental legal concepts as applied in the study of primitive law." The Yale Law Journal 51(6):951-66.

—. 1967. The Law of Primitive Man; A Study in Comparative Legal Dynamics. Cambridge, Mass: Harvard University Press.

Jackson, Jonathan, Ben Bradford, Mike Hough, Andy Myhill, Paul Quinton, and Tom R. Tyler. 2012. "Why do people comply with the law? Legitimacy and the influence of legal institutions." British journal of criminology 52(6):1051-71.

Johnson, Wallace. 1995. "Status and liability for punishment in the T'ang code." Chicago-Kent Law Review 71:217-29. 
Kenrick, Douglas T, and Virgil Sheets. 1993. "Homicidal fantasies." Ethology and Sociobiology 14(4):231-46.

Krotz, Esteban. 2001. Aproximaciones a la antropología jurídica de los mayas peninsulares: Uady.

Leibbrandt, Andreas, and Raúl López-Pérez. 2011. "The dark side of altruistic third-party punishment." Journal of Conflict Resolution 55(5):761-84.

Locke, John. 1988 [1690]. Locke: Two Treatises of Government. Cambridge: Cambridge University Press.

Lorton, David. 1977. "The treatment of criminals in ancient Egypt: through the New Kingdom." Journal of the Economic and Social History of the Orient/Journal de l'histoire economique et sociale de l'Orient:2-64.

Martucci, Roberto. 2002. "En attendant Le Peletier de Saint-Fargeau: la règle pénale au début de la Révolution." Annales Historiques de la Révolution Française 328:77-104.

McCullough, Michael E, Robert Kurzban, and Benjamin A Tabak. 2013. "Cognitive systems for revenge and forgiveness." Behavioral and Brain Sciences 36(01):1-15.

Miethe, Terance D, and Hong Lu. 2005. Punishment: A Comparative Historical Perspective. Cambridge: Cambridge University Press.

Mill, John Stuart. 1991 [1859]. On liberty and other essays: Hymns Ancient and Modern Ltd.

Müller-Wollermann, Renate. 2004. Vergehen und Strafen: zur Sanktionierung abweichenden Verhaltens im alten Ägypten: Brill.

Murray, Aja Louise, Ingrid Obsuth, Manuel Eisner, and Denis Ribeaud. 2016. "Shaping aggressive personality in adolescence: Exploring cross-lagged relations between aggressive thoughts, aggressive behaviour and self-control." Personality and Individual Differences 97:1-7.

Newman, Graeme R. 1976. Comparative Deviance: Perception and Law in Six Cultures. New York: Elsevier.

- 2010. Crime and Punishment around the World [4 volumes]. Santa Barbara: Abc-clio.

Newman, Greame, and Marvin Wiolfgang. 1976. Comparative Deviance: Perception and Law in Six Cultures: Elsevier.

Nivette, Amy E, Manuel Eisner, Tina Malti, and Denis Ribeaud. 2014. "The social and developmental antecedents of legal cynicism." Journal of Research in Crime and Delinquency:0022427814557038.

Nivette, Amy E., and Manuel Eisner. 2012. "Do legitimate polities have fewer homicides? A cross-national analysis." Homicide Studies 17(1):3-26.

Norenzayan, Ara. 2013. Big Gods: How Religion Transformed Cooperation and Conflict. Princeton: Princeton University Press.

Nozick, Robert. 1974. Anarchy, State, and Utopia. New York: Basic Books.

O'Brien, Bruce R. 1999. God's Peace and King's Peace: the Laws of Edward the Confessor. Pittsburgh: University of Pennsylvania Press.

Ostrom, Elinor. 2000. "Collective action and the evolution of social norms." The Journal of Economic Perspectives 14(3):137-58.

Peters, Rudolph. 2005. Crime and Punishment in Islamic law: Theory and Practice from the Sixteenth to the Twenty-first century. Cambridge: Cambridge University Press.

Petersen, Michael Bang, Aaron Sell, John Tooby, and Leda Cosmides. 2010. "Evolutionary Psychology and Criminal Justice: A Recalibrational Theory of Punishment and Reconciliation." Pp. 72-125 in Human Morality and Sociality: Evolutionary and Comparative Perspectives, edited by Henrik Høgh-Olesen. New York: Palgrave.

Pinker, Steven. 2011. The Better Angels of our Nature; Why Violence has Declined. London: Viking.

Price, Michael E, Leda Cosmides, and John Tooby. 2002. "Punitive sentiment as an anti-free rider psychological device." Evolution and Human Behavior 23(3):203-31.

Quinney, Richard. 1970. The Social Reality of Crime. New York: Transaction Publishers.

Reichel, Philip L. 2002. Comparative Criminal Justice Systems: A Topical Approach. Upper Saddle River, NJ: Prentice Hall 
Ribeaud, Denis, and Manuel Eisner. 2015. "The Nature of the Association Between Moral Neutralization and Aggression: A Systematic Test of Causality in Early Adolescence." Merrill-Palmer Quarterly 61(1):68-84.

Richerson, Peter J, and Robert Boyd. 2008. Not by Genes Alone: How Culture Transformed Human Evolution. Chicago: University of Chicago Press.

Robinson, Paul H, and Robert Kurzban. 2006. "Concordance and conflict in intuitions of justice." Minnesota Law Review 91:1829-907.

Robinson, Paul H, Robert Kurzban, and Owen D Jones. 2007. "The origins of shared intuitions of justice." Vanderbilt Law Review 60(6):1633-87.

Roth, Mitchel P. 2014. An Eye for an Eye: A Global History of Crime and Punishment. London: Reaktion Books.

Schwartz, Louis B. 1963. "Morals Offenses and the Model Penal Code." Columbia Law Review 63(4):669-86.

Scott, Samuel Parsons. 1910. The Visigothic Code:(Forum Judicum): Boston Book Company.

Serajzadeh, Seyed Hossein. 2008. "Social determinants of the seriousness of crime: An examination of a Muslim sample." Social Compass 55(4):541-60.

Shahidullah, Shahid M. 2012. Comparative Criminal Justice Systems: Jones \& Bartlett Publishers.

Spierenburg, Pieter. 1984. The Spectacle of Suffering; Executions and the Evolution or Repression: from a Preindustrial Metropolis to the European Experience. Cambridge: Cambridge University Press.

-. 2008. A History of Murder; Personal Violence in Europe from the Middle Ages to the Present. Cambridge: Polity Press.

Spitzer, Manfred, Urs Fischbacher, Bärbel Herrnberger, Georg Grön, and Ernst Fehr. 2007. "The Neural Signature of Social Norm Compliance." Neuron 56(1):185-96.

Stylianou, Stelios. 2003. "Measuring crime seriousness perceptions: What have we learned and what else do we want to know." Journal of Criminal Justice 31(1):37-56.

Tilly, Charles. 1985. "War making and state making as organized crime." Pp. 169-86 in Bringing the State Back In, edited by Peter Evans, Dietrich Rueschemeyer, and Theda Skocpol. Cambridge: Cambridge University Press.

Tooby, John, and Leda Cosmides. 1992. "The psychological foundations of culture." Pp. 19-79 in The Adaped Mind: Evolutionary Psychology and the Generation of Culture, edited by Jerome Barkow, Leda Cosmides, and John Tooby. New York: Oxford University Press.

Trajtenberg, Nico, and Manuel Eisner. 2014. "Hacia una política de prevención de la violencia en Uruguay." University of Cambridge.

Trivers, Robert. 1985. Social Evolution. Menlo Park: Benjamin Cummings.

Tyler, Tom R. 1990. Why People Obey the Law. New Haven: Yale University Press.

—. 2006. " Psychological perspectives on legitimacy and legitimation." Annual review of psychology 57:375-400.

van Loon, A.J. 2014. Law and Order in Ancient Egypt: The development of Criminal Justice from the Pahaonic New Kingdom until the Roman Dominate (Phil Thesis. Leiden: University of Leiden.

Walsh, Anthony. 2000. "Evolutionary psychology and the origins of justice." Justice Quarterly 17(4):841-64.

Wasserman, Ira M. 1983. "A cross-national comparison of contraception and asbortion Laws." Social Indicators Research 13(3):281-309.

Weber, Max. 1978 [1922]. Economy and Society. Berkely: University of California Press.

West, Donald J, and Richard Green (Eds.). 1997. Sociolegal Control of Homosexuality: A Multination Comparison. New York: Springer.

Wilson, Jaqueline. 2014. Blood money in Sudan and Beyond: Restorative Justice or Face-saving Measure? (PhD Dissertation). Washington DC: Georgetown University.

Windrow, Hayden. 2006. "A short history of law, norms, and social control in Imperial China." Asian-Pacific Law and Policy Journal 7(2):244-301.

Wren, Harold G. 1968. "The legal system of Pre-Western Japan." Hastings Law Journal 20:21744. 
Zhang, Boyu, Cong Li, Hannelore De Silva, Peter Bednarik, and Karl Sigmund. 2014. "The evolution of sanctioning institutions: an experimental approach to the social contract." Experimental Economics 17(2):285-303. 
Table $1 \quad$ Serious Crimes and Major Types of Punishment, Examples.

\begin{tabular}{ll}
\hline Civilization & Behaviors considered Crimes \\
\hline Hammurabi & Murder, assault, cattle theft, buying stolen goods, \\
Code & harbouring a runaway slave, burglary, robbery, kidnapping, \\
$(1750 \mathrm{BC})$ & $\begin{array}{l}\text { incest, rape, slander, false accusation, adultery, fraudulent } \\
\text { sale of drink. }\end{array}$
\end{tabular}

Ancient Egypt Homicide, assault, robbery, theft, tomb robbery, insult,

(New Kingdom, slander, adultery, incest, corruption, judicial misconduct,

c 1550-1069 BC) treason, offenses against the gods, blasphemy.

Medieval

England $\left(13^{\text {th }}\right.$ century)

Islamic Cultures

(Sharia Law)

Ancient China

(Qing Code)

$17^{\text {th }} \mathrm{c}$.
Felonies: Homicide, suicide, robbery, larceny, burglary, rape, arson, treason, forgery, serious assault.

Minor crimes: Assault, extortion, abduction, minor theft

Hudud (crimes against god): Drinking alcohol, theft,

highway robbery, illegal sexual intercourse, false accusation of illegal sexual intercourse, apostasy.

Qisas (crimes requiring blood money): murder, assault.

Ta'zir (discretionary offenses): petty theft, attempted

adultery, homosexual contacts, eating pork, false testimony.

10 abominations: Rebellion, sedition, treason, harm or murder one's own parents and grandparents, depravity, great irreverence (show disrespect to the Emperor or his family),

lack of filial piety (maltreat one's parents or grandparents),

discord, unrighteousness (murder one's superiors, mentor, or local government officials), incest.

Also: witchcraft
Punishments

Death penalty, exile, beating, branding,

slavery, fine.

Death penalty (impalement, decapitation, drowning), beating, amputation, slavery, branding, imprisonment, fines

Death penalty (hanging).

Hanawalt (1979)

Death penalty (beheading), amputation, flogging.

Müller-Wollermann (2004), van Loon (2014)

Death penalty, beating with a heavy bamboo, beating with light bamboo,

Shahidullah (2012)
Peters (2005)

Source

Harper (1904)

Peters (2005)

penal servitude, exile. 
Tokugawa Japan Killing and wounding, theft, receiving or buying stolen $\left(17^{\text {th }}-19^{\text {th }} \mathrm{c}\right.$

Aztec Empire

$15^{\text {th }} \mathrm{c}$.) goods, kidnapping, blackmailing and extortion, arson,
forgery, harbouring runaway servants, abandonment of infants, adultery, gambling and the holding of lotteries.

Homicide, perjury, adultery, theft, fraud, bribery, treachery, embezzlement, witchcraft, drunkenness
Death penalty (decapitation,

crucifixation, burning at the stake),

deportation, banishment.

Death penalty (hanging, drowning, stoning, strangulation, impaling, beheading, burning, quartering); exile, restitution, loss of office, destruction of

home, slavery, shaving of the head.

\section{Wren (1968)}

Avalos (1994), Berdan

Note: The list summarizes major crimes and punishments found in the literature. Minor types of delinquency are not included. 
Table 2 Percent adolescents aged 17 years with ruminations of violent second and third party punishment in the past 30 days by sex and serious violent victimization last year.

\begin{tabular}{|c|c|c|c|c|c|c|}
\hline \multirow[b]{2}{*}{$\begin{array}{l}\text { Thinking in the past } 30 \text { days } \\
\text { about the following... }\end{array}$} & \multicolumn{3}{|c|}{$\begin{array}{c}\text { Female } \\
(\mathrm{N}=647)\end{array}$} & \multicolumn{3}{|c|}{$\begin{array}{c}\text { Males } \\
(\mathrm{N}=657)\end{array}$} \\
\hline & $\begin{array}{l}\text { Non- } \\
\text { Victim }\end{array}$ & Victim & $\chi^{2}$ & $\begin{array}{l}\text { Non- } \\
\text { Victim }\end{array}$ & Victim & $\chi^{2}$ \\
\hline $\begin{array}{l}\text { Pay back with violence for something done to } \\
\text { myself }\end{array}$ & $22.3 \%$ & $31.7 \%$ & 1.94 [n.s.] & $48.4 \%$ & $83.3 \%$ & $29.04^{* * *}$ \\
\hline $\begin{array}{l}\text { Kill somebody who insulted my family or } \\
\text { friends }\end{array}$ & $6.6 \%$ & $7.3 \%$ & 0.03 [n.s.] & $11.7 \%$ & $22.7 \%$ & $6.50 *$ \\
\hline $\begin{array}{l}\text { Pay back with violence for something done to } \\
\text { somebody I know }\end{array}$ & $14.9 \%$ & $26.8 \%$ & $4.18^{*}$ & $34.0 \%$ & $66.7 \%$ & 27.08 ** \\
\hline Kill another person & $8.7 \%$ & $6.3 \%$ & 0.74 [n.s.] & $14.7 \%$ & $39.4 \%$ & $25.39 * *$ \\
\hline
\end{tabular}

Note: Data from wave 7 the Zurich Project on the Social development of Children and Adolescents, z-proso. 
Page 32 